\title{
Efek Ekstrak Etanol Daun Salam terhadap Ekspresi VEGF Podosit Glomerulus Tikus Diabetes Melitus
}

\section{The Effects of Aethanol Extracts of Syzygium polyanthum Folium on Glomerular Podocyte VEGF Expression of Rats with Diabetes Mellitus}

\author{
Zulfa Atabaki $i^{1}$, Winarto ${ }^{2}$, Tri Nur $K^{3}$ \\ ${ }^{1}$ STIKES Muhammadiyah Pekajangan Pekalongan Jawa Tengah \\ ${ }^{2}$ Bagian Mikrobiologi Fakultas Kedokteran Universitas Diponegoro Semarang \\ ${ }^{3}$ Program Magister Ilmu Biomedik Fakultas Kedokteran Universitas Diponegoro Semarang
}

\begin{abstract}
ABSTRAK
Stres oksidatif pada diabetes melitus meningkatkan ekspresi VEGF podosit glomerulus sehingga menyebabkan disfungsi endotel. Daun salam mengandung antioksidan yang dapat menghambat ekspresi VEGF. Penelitian ini membuktikan pemberian Ektrak Etanol Daun Salam (EEDS) dapat menurunkan ekspresi VEGF podosit glomerulus tikus Sprague dawley diabetes melitus. Sampel 20 tikus Sprague dawley jantan diabetes melitus dibagi 4 kelompok: Kelompok EEDS (-), kelompok EEDS(+): dosis $150 \mathrm{mg} / 200 \mathrm{grBB} ; 300 \mathrm{mg} / 200 \mathrm{grBB} ; 450 \mathrm{mg} / 200 \mathrm{grBB}$ selama 15 hari. Rerata allred score ekpresi VEGF pada kelompok kontrol $(1,2 \pm 1,09)$, dosis satu $(1,3 \pm 1,15)$, dosis dua $(0,50 \pm 1,00)$, dosis tiga $(0,00)$. Analisa Krusskall Wallis menunjukkan tidak ada perbedaan ekspresi VEGF podosit glomerulus diantara masing-masing kelompok $(p=0,20)$. Dosis $450 \mathrm{mg} / 200 \mathrm{gr} \mathrm{BB}$ dapat menurunkan ekspresi VEGF walaupun tidak bermakna $(p=0,07)$. Berdasarkan penelitian ini disimpulkan, EEDS tidak dapat menurunkan ekspresi VEGF podosit glomerulus tikus Sprague dawley diabetes melitus.
\end{abstract}

Kata Kunci: Daun salam, diabetes melitus, VEGF podosit glomerulus

\begin{abstract}
Oxidative stress in diabetes mellitus increases glomerular podocyte VEGF expression which causes endothelial dysfunction. Bay leaves contain antioxidant which can inhibit the expression of VEGF. This study aims to prove whether administration of ethanol extract of Syzygium polyanthum Folium (EEDS) can decrease glomerular podocyte VEGF expression among diabetic Sprague dawley rats. A sample of 20 male Sprague Dawley rats with diabetes mellitus was divided into 4 groups, i.e. EEDS group (-); EEDS group (+) with doses of $150 \mathrm{mg} / 200 \mathrm{gBW} ; 300 \mathrm{mg} / 200 \mathrm{gBW} ; 450 \mathrm{mg} / 200 \mathrm{gBW}$ for 15 days. Allred mean of glomerular podocyte VEGF expression score in the control group $(1,2 \pm 1,09)$, first dose $(1,3 \pm 1,15)$, second dose $(0,50 \pm 1,00)$ and third dose $(0,00)$. Krusskall Wallis analysis showed no differences of glomerular podocyte VEGF expression in each group $(p=0,20)$. At dose of $450 \mathrm{mg} / 200 \mathrm{gBW}$, glomerular podocyte VEGF expression is decreasing slightly $(p=0,07)$. It can be concluded that EEDS could not decrease glomerular podocyte VEGF expression in diabetic Sprague dawley rats.
\end{abstract}

Keywords: Diabetes Mellitus, syzygium polyanthum, glomerular podocyte VEGF

Jurnal Kedokteran Brawijaya, Vol. 28, No. 4, Agustus 2015; Korespondensi: Zulfa Atabaki. STIKES Muhammadiyah Pekajangan Pekalongan, JL. Raya Ambokembang, No.8, Kedungwuni, Pekalongan Jawa Tengah Tel. (0285) 785179 Email: zulfaatabaki@ymail.com 


\section{PENDAHULUAN}

Diabetes Mellitus (DM) merupakan kumpulan beberapa kelainanvaskular dan metabolik dari berbagai penyebab (1). Pasien diabetes $20 \%-40 \%$ akan berkembang menjadi nefropati diabetik (2). Komplikasi mikrovaskuler dan makrovaskuler penyebab utama peningkatan morbiditas dan mortalitas pada DM tipe I dan tipe 2 (3). Ekspresi VEGF podosit meningkat pada fase awal diabetik nefropati yang dipengaruhi oleh beberapa mediator diantaranya hiperglikemia sebagai penyebab hipoksia, angiotensin, spesies oksigen reaktif (ROS), Advanced glycation end products (AGEs). VEGF berperan dalam disfungsi endothelial dan vasculopathy (2-8).

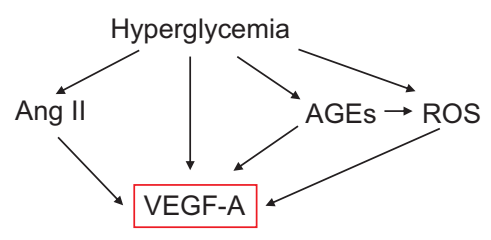

\section{Gambar 1. Pathways peningkatan VEGF pada diabetes melitus}

Sumber: Alda Tufro \& Delma Veron, 2012

Stres oksidatif pada diabetes mellitus hasil dari Reactive Oxygen Species (ROS) dan Reactive Nitrogen Species (RNS) berlebih, yang berasal dari angiotensin $\mathrm{I}^{7}$, oksidasi glukosa, dan AGEs, yang tidak dibersihkan oleh antioksidan (SOD, katalase, glutathione peroxidase). ROS/RNS meningkatkan VEGF dengan menstabilkan HIF$1 \alpha(9)$.

Daun salam (Syzygium polianthum) merupakan salah satu tanaman obat populer yang digunakan di Indonesia selain daun kari (Murraya koenigii dan rimpang jahe (Zingeber purpurea). Kandungan antioksidan (flavonoid) tertinggi dari ketiga tanaman diatas terdapat pada daun salam (10). Secara empiris, daun salam dapat digunakan sebagai anti diabetikum melalui penghambatan alpha glucosidase (95\%) dan antioksidan (87\%) (5,11-16). Penelitian mengenai manfaat daun salam untuk menurunkan gula darah secara empiris sudah banyak dilakukan, namun dampak peningkatan dula darah (hiperglikemia) pada diabetes melitus dapat meningkatkan ekspresi VEGF. Hal ini mendorong perlu dilakukan penelitian eksperimental antioksidan yang terkandung dalam daun salam apakah selain menurunkan gula darah, dapat menurunkan ekspresi VEGF podosit glomerulus.

\section{METODE}

Penelitian ini merupakan true experimental dengan menggunakan pendekatan post test only control group design (6). Penelitian ini dilakukan di LPPT IV UGM Yogyakarta. Sampel dalam penelitian ini adalah tikus Sprague dawley diabetes melitus, jenis kelamin jantan, dengan berat badan 50-200 gram, berusia 45-75 hari. Hewan coba terdiri dari 20 ekor, dibagi menjadi empat kelompok, yaitu satu kelompok kontrol dan tiga kelompok perlakuan. Pada kelompok perlakuan diberikan ekstrak etanol daun salam (EEDS) dengan dosis: $150 \mathrm{mg} / 200 \mathrm{gram}$ BB, 300mg/200gram BB dan 450mg/200gram BB. Metode diabetic rat (GDS: $\geq 200 \mathrm{mg} / \mathrm{dl}$ ) dengan diinjeksi
Streptozotocin dosis $40 \mathrm{mg} / \mathrm{kgBB}$ secara intraperitoneal (17-24).

Studi awal dilakukan dengan menginduksi STZ $40 \mathrm{mg} / \mathrm{BB}$ pada empat ekor tikus, dua dipuasakan selama 12 jam dan dua tanpa puasa. GDS diperiksa pada hari ke-2, ke-4 dan ke-6 dan GDS tetap lebih dari $200 \mathrm{mg} /$ dl pada hari ke-4 pasca induksi. Pemeriksaan GDS dilakukan di laboratorium Klinik Pramita Yogyakarta dengan menggunakan metode hexokinase.

Daun salam diambil dari satu pohon di Desa Limbangan Boja Kendal. Determinasi sampel daun salam dilakukan di Bagian Biologi Farmasi UGM. Ekstraksi maserasi daun salam dilakukan di LPPT I UGM dengan berat serbuk daun salam 700gram, ethanol $70 \%$ dan berat ekstrak daun salam 45,12 gram. Ekstrak daun salam dilarutkan dalam larutan Carboxy Methyl Cellulose Natrium (CMC Na) 0,5\% untuk mempermudah homogenisasi. Uji kualitatif (fitokimia) untuk mengetahui kandungan zat aktif pada daun salam dan uji antioksidan dengan metode DPPH pada ekstrak etanol daun salam yang dibandingkan dengan vitamin C dilakukan di Fakultas MIPA Undip. Tikus diperiksa GDS setelah 15 hari diberikan EEDS dan diterminasi, organ ginjal dibuat sediaan histopatologi dinilai ekspresi VEGF podosit glomerulus ginjal berdasarkan kriteria Allred score dan jumlah sel podosit diamati menggunakan mikroskop pembesaran 200x.

Pemeriksaan IHC dilakukan di laboratorium Patologi Anatomi RS dr Sardjito Yogyakarta dengan menggunakan antibodi sekunder atau trekkie universal link. Penentuan ekpresi VEGF glomerulus ginjal menggunakan allred score: penjumlahan nilai proporsi dan intensitas. Proporsi (0-5) 0: tidak terwarnai, 1 : $\leq 1 / 100$ sel terwarnai, $2: \leq 1 / 10$ sel terwarnai, $3: \leq 1 / 3$ sel terwarnai, $4: \leq 2 / 3$ sel terwarnai, 5 : semua sel terwarnai. Nilai intensitas (0-3); 0 : tidak ada pewarnaan, 1: pewarnaan ringan, 2: pewarnaan sedang, dan 3: pewarnaan gelap.

Data hasil penelitian yang berupa ekspresi VEGF podosit glomerulus dianalisis dengan program SPSS. Analisis data dengan uji Krusskall-Wallis dilanjutkan uji Mann-Whitney. Data ekspresi VEGF podosit glomerulus didapatkan dari pembacaan oleh dua pengamat yang berkompeten di bidang Patologi Anatomi FK UGM yang telah dilakukan uji reliabilitas. Analisis uji $t$ dependent digunakan untuk mengetahui perbedaan rata-rata GDS Pre EEDS dengan GDS Post EEDS.

\section{HASIL}

Efek EEDS terhadap terhadap Kadar Gula Darah Sewaktu (GDS)

Rata-rata hasil pemeriksaan GDS untuk menentukan kestabilan hewan coba dalam kondisi tetap diabetes melitus pada hari kedua, keempat dan keenam. Rata-rata GDS pada sampel puasa satu $370,33 \mathrm{mg} / \mathrm{dl}$, sampel puasa dua 432,33, sampel non puasa satu 399,67 dan sampel non puasa dua yaitu 454 . Rata-rata gula darah sewaktu pada uji pendahuluan masih dalam kondisi diabetes melitus. Peneliti mengambil keputusan bahwa untuk penelitian selanjutnya, kondisi hewan coba sudah stabil diabetes melitus pada hari kempat dan dipuasakan terlebih dahulu 12 jam sebelum induksi streptozotocin. Hasil uji fitokimia ekstrak daun salam secara kualitatif tampak pada Tabel 1. Flavonoid yang terkandung dalam daun salam sebagai antioksidan dapat meregulasi gula darah sewaktu $(4,5)$. 
Tabel 1. Hasil uji fitokimia ekstrak etanol daun salam

\begin{tabular}{ll}
\hline Parameter & Ekstrak \\
\hline Alkaloid & Positif \\
Saponin & Positif \\
Quinon & Positif \\
Fenolik & Positif \\
Triterpenoid & Positif \\
Steroid & Positif \\
Flavonoid & Positif \\
\hline
\end{tabular}

Hasil uji antioksidan dengan metode difenilpikril hidrasil (DPPH) pada ekstrak etanol daun salam yaitu $I_{50}=89.627$, konsentrasi senyawa antioksidan yang terkandung dalam daun salam menyebabkan lebih dari 50\% DPPH mengalami penurunan karakter radikal bebas lebih besar dari vitamin $C$ yaitu $\mathrm{IC}_{50}=7.587$ sedangkan pada daun salam IC $\mathrm{C}_{50}=89.627$.

Tabel 2. Gula darah sewaktu pre EEDS dan post EEDS

\begin{tabular}{cccc}
\hline GDS & Mean \pm SD & p value & Jumlah \\
\hline Pre EEDS & $356,5 \pm 121,47$ & \multirow{2}{*}{0,006} & 16 \\
Post EEDS & $332,5 \pm 149,15$ & & \\
\hline
\end{tabular}

Hasil analisis menunjukkan bahwa rata-rata GDS Pre EEDS adalah $356,5 \mathrm{mg} / \mathrm{dl}$ dengan standar deviasi $121,47 \mathrm{mg} / \mathrm{dl}$. Setelah pemberian EEDS rata-rata GDS adalah $332,5 \mathrm{mg} / \mathrm{dl}$ dengan standar deviasi 149,15mg/dl. Hasil analisis uji t dependent terhadap perbedaan rata-rata GDS Pre EEDS dengan GDS Post EEDS menunjukan ada perbedaan yang signifikan antara GDS Pre EEDS dengan GDS Post EEDS ( $p$ value $=0,006$ ). Seperti pada penelitian sebelumnya bahwa flavonoid yang terkandung pada daun salam dapat meregulasi gula darah $(5,7,9)$. Hal ini menunjukkan bahwa dosis tersebut dapat meregulasi gula darah sewaktu terutama pada dosis daun salam 300mg/200gr BB, dibanding dosis satu dan dua. Jumlah sampel pada penelitian ini 16 ekor dan tidak digantikan oleh tikus lain karena persediaaan terbatas.

\section{Efek EEDS terhadap Ekpresi VEGF Podosit Glomerulus Ginjal}

Allred score ekspresi VEGF menunjukkan pada kelompok kontrol sebagian besar adalah dua dengan nilai proporsi satu (pada pengamatan terdapat $\leq 1 / 100$ sel terwarnai) dan nilai intensitas satu (pewarnaan ringan), pada kelompok perlakuan dosis satu, nilai allred score sebagian besar dua. Pada kelompok dosis tiga hanya satu dengan nilai alllred score 2 dan pada kelompok dosis tiga sebagian besar nilai allred score nol dengan proporsi nol (sel tidak terwarnai) dan nilai intensitas nol (tidak ada pewarnaan). Rata-rata allred score setelah diberikan ekstrak daun salam selama 15 hari ditunjukkan pada Tabel 3.

Tabel 3. Allred score ekpresi VEGF hewan uji berdasarkan dosis pemberian EEDS

\begin{tabular}{ccrrc}
\hline Karakteristik & Kel. & Mean \pm SD & Med & P value \\
\hline VEGF & Kontrol & $1,2 \pm 1,09$ & 2 & \\
& Dosis 1 & $1,3 \pm 1,15$ & 2 & \multirow{2}{*}{0,20} \\
& Dosis 2 & $0,50 \pm 1,00$ & 0 & \\
& Dosis 3 & 0,00 & 0 & \\
\hline
\end{tabular}

Berdasarkan Tabel 3, diketahui bahwa rata-rata Allred score VEGF kelompok kontrol adalah 1,2 $\pm 1,09$, kelompok dosis 1 adalah 1,3 $\pm 1,15$ dan kelompok dosis 2 adalah $0,50 \pm 1,00$ sedangkan rata-rata score VEGF kelompok dosis 3 adalah 0 . Hasil uji statistik Krusskall-Wallis menunjukkan bahwa tidak ada perbedaan score VEGF diantara masingmasing kelompok penelitian ( $p>0,05)$. Uji Mann-Whitney untuk mengetahui perbedaan rerata score VEGF pada masing-masing kelompok dibandingkan dengan kelompok kontrol dengan $\mathrm{p}$ value sebagai berikut: kontrol vs dosis 1 (150mg/200gr BB) p value $=0,86$ sedangkan kontrol vs dosis 2 (300mg/200gr BB) p value $=0,32$ dan kontrol vs dosis 3 (450mg/200gr BB) p value $=0,07$.

Allred score ekspresi VEGF podosit glomerulus pada kelompok penelitian sebagian besar dengan nilai nol dan dua dengan nilai proporsi dan intensitas yang sama, ditampilkan pada Gambar 1 dan 2.

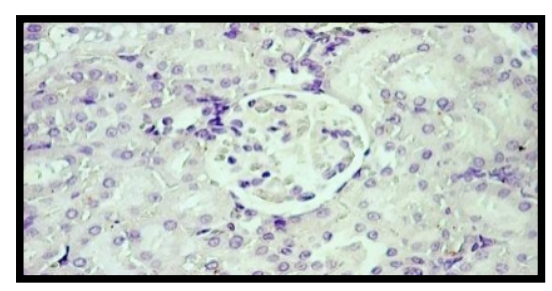

Gambar 1. Ekspresi VEGF podosit glomerulus ginjal tikus SD (K-2) dengan proportion score (PS): 0 dan intensity score (IS): 0 , pada pembesaran gambar $200 x$

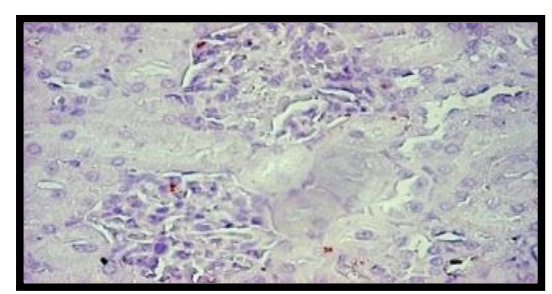

Gambar 2. Ekspresi VEGF podosit glomerulus ginjal tikus SD (P1-5) hari ke- 15 post EEDS dengan proportion score (PS): 1 dan intensity score (IS): 1, pada pembesaran gambar 200x

\section{DISKUSI}

\section{Efek EEDS terhadap Kadar Gula Darah Sewaktu (GDS)}

Hasil uji fitokimia ekstrak daun salam menunjukkan bahwa zat yang terkandung dalam daun salam berupa alkaloid, saponin, fenolik, triterpenoid, steroid, dan flavonoid. Flavonoid sebagai zat anti oksidatif, yang dapat berfungsi menurunkan gula darah. Hasil studi menunjukkan ekstrak daun salam berpotensi dalam penghambatan aktivitas alpha glucosidase pada diabetes melitus pada dosis 100 $\mathrm{mg} / \mathrm{kg}$ BB dalam 21 hari, ekstrak daun salam dapat menurunkan gula darah puasa $(5,7,9)$. Hasil uji antioksidan dengan metode difenilpikril hidrasil (DPPH) pada ekstrak etanol daun salam yaitu $\mathrm{IC}_{50}=89.627$, konsentrasi senyawa antioksidan yang terkandung dalam daun salam memyebabkan lebih dari 50\% DPPH mengalami penurunan karakter radikal bebas lebih besar dari vitamin C yaitu IC $_{50}=7.587$.

Flavonoid sebagai salah satu kelompok senyawa fenolik yang memiliki sifat antioksidatif serta berperan dalam 
mencegah kerusakan sel dan komponen selularnya oleh radikal bebas reaktif. Peran antioksidan flavonoid dengan cara mendonasikan atom hidrogennya atau melalui kemampuannya mengelat logam, berada dalam bentuk glukosida (mengandung rantai samping glukosa) atau dalam bentuk bebas yang disebut aglikon (25).

\section{Efek EEDS terhadap Ekpresi VEGF Podosit Glomerulus Ginjal}

Hasil penelitian menunjukkan bahwa setelah diberikan EEDS selama 15 hari nilai allred score ekspresi VEGF menunjukkan pada kelompok kontrol sebagian besar adalah dua dengan nilai proporosi satu, (apabila pada pengamatan terdapat $\leq 1 / 100$ sel terwarnai) dan nilai intensitas satu (pewarnaan ringan), pada kelompok perlakuan dosis satu, nilai allred score sebagian besar dua. Pada kelompok dosis tiga hanya satu dengan nilai alllred score 2 dan pada kelompok dosis tiga sebagian besar nilai allred score nol dengan proporsi nol (sel tidak terwarnai) dan nilai intensitas nol (tidak ada pewarnaan) sehingga ekspresi VEGF tidak tampak. Hal ini seperti dijelaskan pada penelitian sebelumnya bahwa ekpresi VEGF muncul dimulai pada 10 hari paska induksi, namun pada kelompok perlakuan, paska induksi hari kelima sudah mendapatkan terapi ekstrak daun salam sehingga ekspresi VEGF podosit kelompok perlakuan nilai allred score hanya dua, kemungkinan karena dihambat oleh EEDS.

Allred score ekpresi VEGF masing-masing kelompok sampel menunjukkan semakin tinggi dosis EEDS yang diberikan semakin rendah nilai $p$ value. Hal tersebut menunjukkan bahwa semakin tinggi dosis EEDS yang diberikan, ekspresi VEGF podosit glomerulus dapat dihambat atau tidak muncul.

Beberapa mediator mengatur ekspresi VEGF pada ginjal diabetes. Sekresi VEGF terutama disebabkan oleh hipoksia (26). Model hewan diabetes melitus tipe I, pada tikus diabetes yang diinduksi streptozotosin (STZ) mengalami hipoksia ginjal (27). Hipoksia berperan dalam penyakit ginjal stadium awal dan terjadi sebelum ditemukan jejas pada struktur tubulo interstisial. Gangguan pada kapiler glomerulus, seperti glomerulosklerosis, mengakibatkan penurunan perfusi peritubular dan asupan oksigen tubulus. Peningkatan kebutuhan metabolisme, sel mungkin mengalami keadaan hipoksia relatif walaupun aliran darah normal. Pada penelitian menggunakan teknik blood oxygen leveldependent (BLOD), magnetic resonance imaging (MRI) menunjukkan induksi streptozotosin pada ginjal penderita diabetes terjadi hipoksia jaringan pada fase awal, sebelum terjadi perubahan struktur (28). Penurunan pO2 di medula ginjal menimbulkan hipoksia yang diinduksi oleh Hypoxia-Inducible Factor (HIF). Faktor ini mengatur transkripsi VEGF mRNA. Kadar glukosa tinggi (HG) merangsang produksi VEGF di podosit, melalui aktivasi protein kinase C (PKC) dan Extracellular signal-regulated kinase (ERK) $(26,29)$.

Hiperglikemia juga mengatur Angiotensin II (Ang II) dalam sel tubulus proksimal tikus, yang menginduksi ekspresi VEGF melalui spesies oksigen reaktif (ROS) dan jalur ERK. Advanced glycation end products (AGEs) mengatur tingkat VEGF mRNA melalui faktor transkripsi seperti nuclear factor-kB (NF-kB) dan aktivator protein-1 (AP-1). Selain itu, transforming growth factor- $\beta 1$ (TGF- $\beta$ 1) ,yang diekspresikan dalam sel endotel glomerulus diabetes, meningkatkan konsentrasi protein VEGF pada sel epitel tubular tikus (27). Didalam ginjal, menunjukkan bahwa hiperglikemi dapat meningkatkan aktivitas PKC yang menyebabkan aktivasi dari beberapa isoform dari nicotinamide adenine dinucleotide phospate (bentuk turunan; NADPH) oksidase, sehingga menghasilkan oksidan yang berlebihan. Peningkatan kadar oksidan yang berkombinasi dengan PKC menyebabkan aktivasi mitogenactivated kinase menyebabkan produksi berlebihan fibrotic growth factor. Stres oksidatif pada diabetes melitus merupakan hasil dari oksigen dan nitrogen spesies reaktif berlebih (ROS/RNS) yang berasal dari angiotensin II7, oksidasi glukosa, dan AGEs, yang tidak dibersihkan oleh antioksidan (SOD, katalase, glutathioneperoxidase). ROS/RNS meningkatkan VEGF dengan menstabilkan HIF$1 \alpha(25)$.

Pada stase awal diabetes ekspresi VEGF pada glomerulus meningkat $(2,18,29,30)$. Pada ginjal manusia VEGF dapat dilihat pada podosit, sel tubular distal dan sel tubular proksimal $(2,3,31)$. Hal ini menunjukkan bahwa ekpresi VEGF pada diabetes melitus tidak hanya diamati pada glomerulus ginjal. Hasil penelitian menunjukkan bahwa ekspresi VEGF podosit glomerulus terdapat pada kelompok kontrol dan kelompok perlakuan satu dan dua dengan allred score sangat lemah,namun pengamatan pada tubulus ginjal ekpresi VEGF banyak ditemukan disemua kelompok.

Secara klinik bahwa neogenesis pada diabetes ditandai pada retina,yaitu hasil dari perdarahan vitreal dan fibrosis. Proliferasi vaskuler yang ada pada mata juga ditemukan pada pada ginjal. Pada biopsi ginjal diabetes menunjukkan bahwa terjadi perubahan pembuluh darah berupa peningkatan diameter, panjang pembuluh darah dan proliferasi pembuluh darah baru di vascular pole, kapsul bowman yang mengelilingi kandung kemih. Selama fase angiogenik awal nefropati diabetik, VEGF meningkat pada podosit ginjal seperti peningkatan VEGFyang ditemukan dalam sel-sel retina (32).

Pada model hewan diabetes, studi Nyengaard dan Rasch telah mengidentifikasi kapiler glomerulus abnormal yang disebabkan oleh streptozotocin menunjukkan bahwa baru hari ke-10 dan 50 hari setelah induksi, total rata-rata luas permukaan, panjang, dan jumlah kapiler glomerulus yang meningkat dibandingkan dengan kelompok kontrol(32). Hasil penelitian menunjukkan bahwa pada kelompok kontrol, pasca induksi STZ hari ke-19 dilakukan pemeriksaan IHC menunjukkan allred score ekpresi VEGF podosit glomerulus dua.

Diabetes adalah gangguan metabolisme yang ditandai dengan gangguan sekresi insulin endogen dan aktivitas, mengurangi produksi No dan peningkatan produksi radikal bebas, atau gangguan pertahanan antioksidan. Faktor utama dalam komplikasi diabetes yang diperantarai adalah disfungsi endotel. Beberapa faktor risiko yang dapat menyebabkan kerusakan sel endotel diabetes seperti hiperglikemia, resistensi insulin, dislipidemia, peningkatan stresoksidatif, inflamasi, dan hipertensi.

Terapi antioksidan telah menjadi pilihan yang mudah dan terkenal untuk mengurangi kelainan pembuluh darah yang diperantarai diabetes. Penelitian ini menunjukkan bahwa pada EEDS dosis ketiga menunjukkan bahwa ekspresi VEGF podosit glomerulus sangat ditekan atau dihambat sehingga tidak tampak ekpresi VEGF. Hal ini sejalan dengan penelitian bahwa terapi antioksi dan seperti vitamin $\mathrm{C}$ dan 
E dapat untuk menurunkan kadarperoxynitrite, bila dalam konsentrasi yang sangat tinggi (33). Terapi tunggal mungkin tidak cukup meningkatkan fungsi endotel, sehingga perlu untuk menargetkan beberapa faktor untuk intervensi terapi disfungsi endotel. Penelitian sebelumnya menunjukkan bahwa ada peningkatan respon relaksasi endotelium dengan berbagai agen antioksidan, termasuk superoksida dismutase (SOD). Penelitian ini menguatkan paradigma baru bahwa terapi antioksidan saja tidak cukup. Terapi antioksidan adalah pilihan yang harus digunakan dalam kombinasi dengan terapi lain untuk mengurangi kelainan pembuluh darah. Terapi antioksidan hanya menunda disfungsi endotel diabetes yang diinduksi, daripada memberikan pemulihan lengkap (33).

Hasil penelitian ini membuktikan bahwa pemberian EEDS secara statistik tidak dapat menurunkan ekpresi VEGF

\section{DAFTAR PUSTAKA}

1. Kota SK, Meher LK, Jammula S, Kota SK, Krishna SVS, and Modi KD. Aberrant Angiogenesis: The Gateway to Diabetic Complications. Indian Journal of Endocrinology and Metabolism. 2012; 16(6): 918-930.

2. Mironidou-Tzouveleki M, Tsartsalis S, and Tomos C. Vascular Enothelial Growth Factor (VEGF) in the Pathogenenesis of Diabetic Nephropathy of Type I Diabetes Mellitus. Current Drug Target. 2011; 12(1): 107-114.

3. Khamaisi M, Schrijvers BF, De Vriese AS, Raz I, and Flyvbjerg A. The Emerging Role of VEGF in Diabetic Kidney Disease. Nephrology Dialysis Transplantation. 2003 Aug; 18(8): 1427-1430.

4. Kusuma IW, Kuspradini H, Arung ET, et al. Biological Activity and Phytochemical Analysis of Three Indonesian Medicinal Plants, Murraya koenigii, Syzygium polyanthum and Zingiber purpurea. Journal of Acupuncture and Meridian Studies. 2011; 4(1): 7579.

5. Lelono RAA and Tachibana S. Preliminary Studies of Indonesian Eugenia polyantha Leaf Extracts as Inhibitors of Key Enzymes for Type 2 Diabetes. Journal of Medical Sciences. 2013; 13(2): 103-110.

6. Giacco F and Brownlee M. Oxidative Stress and Diabetic Complication. Circulation Research Archives. 2010;107(9): 1058-1070.

7. Nangaku M. Chronic Hypoxia and Tubulointerstitial Injury: A Final Common Pathway to End-Stage Renal Failure. Journal of American Society of Nephrology. 2006; 17(1): 17-25.

8. Cha DR, Kang YS, Han SY, et al. Vascular Endothelial Growth Factor is Increased During Early Stage of Diabetic Nephropathy in Type II Diabetic Rats. Journal of Endocrinologi. 2004; 183(1): 183-194

9. Tufro A and Veron D. VEGF And Podocytes in Diabetic Nephropathy. Seminars in Nephrology. 2012; 32(4): 385-393

10. Har LW and Ismail IS. Antioxidant Activity, Total Phenolic and Total Flavonoids of Syzygium Polianthum (Wight) Walp Leaves. International Journal of Medicinal and Aromatic Plants. 2012; 2(2): 219-228. podosit glomerulus diantara kelompok perlakuan dan kontrol ( $p=0,20, p>0,05)$, namun rata-rata allred score pada masing-masing kelompok, semakin tinggi dosis semakin rendah ekspresi VEGF podosit glomerulus. Hal ini sejalan dengan penelitian bahwa terapi antioksidan seperti vitamin $\mathrm{C}$ dan $\mathrm{E}$ dapat untuk menurunkan kadar peroxynitrite, bila dalam konsentrasi yang sangat tinggi. Terapi tunggal mungkin tidak cukup meningkatkan fungsi endotel, sehingga perlu untuk menargetkan beberapa faktor untuk intervensi terapi disfungsi endotel (33). Penelitian selanjutnya disarankan bahwa ekspresi VEGF dapat diamaati pada podosit, sel tubular distal dan sel tubular proksimal. Pemberian EEDS sebaiknya diberikan lebih dari 5 hari paska induksi sehingga proporsi dan intensitas allred score ekpresi VEGF dapat diamati lebih jelas.

11. Departemen Kesehatan Republik Indonesia. Materia Medika Indonesia. Jakarta: Depkes RI; 1980.

12. Yohana A dan Yovita A. Khasiat Tanaman Obat. Jakarta: Pustaka Buku Murah; 2008

13. Mun'im A dan Hanani E. Fitoterapi Dasar Jakarta: Dian Rakyat; 2011

14. Sumono A dan Wulan A. The Use of Bay Leaf (Eugenia polyantha Wight) in Dentistry. Dental Journal. 2008; 41(3): 147-150.

15. Cao Z and Cooper ME. Pathogenesis of Diabetic Nephropathy. Journal of Diabetes Investigation. 2011; 2(4): 243-247.

16. Sastroasmoro S dan Ismael S. Dasar-dasar Metodologi Penelitian Klinis. 3rd ed. Jakarta: Sagung Seto; 2008.

17. Salmon AH, Neal CR, Bates DO, and Harper SJ. Vascular Endotheial Growth Factor Increaes the Ultrafiltration Coefficient in Isolated Intact Wistar Rat Glomeruli. The Journal of Physiology. 2006; 570(1): 141-156.

18. Szkudelski T. The Mechanisme of Alloxan and Streptozotocin Action in B Cell of the Rat Pancreas. Physiological Research. 2001; 50(6): 537-546.

19. Akbarzadeh A, Norouzian D, Mehrabi MR, et al. Induction of Diabetes by Streptozotocin in Rats. Indian Journal of Clinical Biochemistry. 2007; 22(2): 60-64.

20. Arora S, Ojha SK, and Vohora D. Characterisation of Streptozotocin Induced Diabetes Mellitus in Swiss Albino Mice. Global Journal of Pharmacology. 2009; 3(2): 81-84.

21. Sulistyoningrum E dan Setiawati. Phaleria Macrocarpha Reduces Glomerular Growth Factor Expression in Alloxan- Induced Diabetic Rats. Universa Medicina. 2013; 32(2): 71-79.

22. Tesch GH and Allen TJ. Rodent Models of Streptozotocin-Induced Diabetic Nephropathy. Nephrology. 2007; 12(3): 261-266.

23. Studiawan $\mathrm{H}$, Santosa MH. Uji Aktifitas Penurunan Kadar Gula Darah Ekstrak Daun Eugenia Poliantha pada Mencit yang Diinduksi Alloxan. Media Kedokteran Hewan. 2005; 21(2): 62-65.

24. Liu E, Morimoto M, Kitajima S, et al. Increased Expression of Vascular Endothelial Growth Factor in Kidney Leads to Progressive Impaiment of Glomerular 
Functions. Journal American Society of Nephrology. 2007; 18(7): 2094-2104.

25. Schlingemann RO, Van Noorden CJ, Diekman MJ, et al. VEGF Levels in Plasma in Relation to Platelet Activation, Glycemic Control,and Microvascular Complications in Type 1 Diabetes. Diabetes Care. 2013; 36(6): 1629-1634.

26. Schrijvers BF, Flyvbjerg A, and De Vriese AS. The Role of Vascular Endothelial Growth Factor (VEGF) in Renal Pathophysiology. Kidney International. 2004; 65(6): 2003-2017.

27. Murnah. Pengaruh Ekstrak Etanol Mengkudu (Morinda citrifolia L) terhadap Diabetik Nefropati pada Tikus Srague Dawley yang Diinduksi Streptozotosin dengan Kajian VEGF dan Mikroalbuminuria. [Tesis]. Universitas Diponegoro, Semarang. 2011.

28. Christoper C. Osmoregulation II. Animal Sciences Bio
131 with Thometz at Univercity of California-Santa cruz. (Online) 2012. https://www.studyblue.com/ notes/note/n/osmoregulation-ii/deck/6365072.

29. Sastrawan IGP dan Suwitra K. Peran Hipoksia pada Patogenesis Penyakit Ginjal. Jurnal Penyakit Dalam. 2008; 9(1): 75-84.

30. Melhelm MF, Craven PA, Liachenko J, and DeRubertis FR. $\alpha$-Lipoic Acid Attenuates Hyperglycemia an Prevents Glomerular Mesangial Matrix Expansion in Diabetes. Journal of American Society of Nephrology. 2002; 13(1): 108-116.

31. Nakagawa T, Kosugi T, Haneda M, Rivard CJ, and Long DA. Abnormal Angiogenesis in Diabetic Nephropathy. Diabetes. 2009; 58(7): 1471-1478.

32. Sivaskandarajah GA, Jeansson M, Maezawa Y, Eremina $\mathrm{V}$, Baelde HJ, and Quaggin SE. VEGF-A Protects the Glomerular Microvasculature in Diabetes. Diabetes Journal. 2012;61(11): 2958-2966. 